\title{
Transmission of M. Leprae to Mice and Identification of Increased Bacilli in Injected Animals
}

\author{
SHINJI NISHIMURA \\ Department of Leprosy, Research Institute for Microbial Diseases, \\ Osaka University
}

\section{INTRODUCTION}

We have conducted the following experiments in the past in attempt to transmit $M$. leprae to animals. From 1942 to $1947,{ }^{1)}$ human leprosy, murine leprosy and other acid-fast bacilli were inoculated into the pectoral muscle of chicken according to the method of Ota and Nitto. In 1947,1) rabbits, guinea pigs and rats were inoculated subcutaneously with the human and murine leprosy bacilli and the characteristics of the local inflammatory reaction and the fate of the bacteria investigated. In 1952,1$)$ the eye of healthy rabbit, guinea pig and rat was wounded and human and murine leprosy bacilli inoculated in the anterior chamber in an attempt to find out whether the eye has a special affinity for the organism.

Sensitivity of the golden hamster to human and murine leprosy bacilli was studied by subcutaneous and intraperitoneal inoculation at the same year. ${ }^{2}$ ) In $1955,3)$ sensitivity studies were conducted with the murine leprosy bacillus on various strains of mice and it was found that the Japanese black mouse (the BK strain) was highly sensitive.

Similar experiments were carried out in 19604) on strains of wild rodents. The effect of cortisone was also studied at the same time.

From the findings in these studies, it is believed that the following are the necessary conditions for the successful transplantation of the leprosy bacillus to animals.

1) Histiocytes and histiocyte-like cells of animals sensitive to the leprosy bacillus are hereditarily endowed with certain factors required for growth of the bacillus but on the other hand the animal possesses resistence by which growth of the bacillus is suppressed and infection is prevented when resistence is high. Growth, however, will not take place no matter how much resistence is lowered in animals which do not possess the factors required for growth of the bacillus. It is therefore necessary to find animals which fulfill these requirements.

2) The sensitivity of animals to in vivo proliferating acid-fast bacteria such as the murine leprosy bacillus and the human leprosy bacillus differs greatly not only according to species but individually. Experiments should therefore be carried out in many young animals of many strains, and observe for long periods (1-2 years) after inoculation. 


\section{PRESENT EXPERIMENT}

The mouse was selected as several inbred strains with high sensitivity to the tubercle bacillus have been reported and it was hoped that similar strains with sensitivity to the leprosy bacillus could be found. The black mouse was first selected as it was previously found that the BK strain (Japanese black mouse) has a high sensitivity to the murine leprosy bacillus and also because a black mouse with high sensitivity to the human leprosy bacillus was reported by Chatterjee. ${ }^{5}$ )

Experiments were carried out in 6 strains including 4 strains of black (ICF, BK, $\left.\mathrm{C}_{57} \mathrm{BL}, \mathrm{BTK}\right)$ and the Agouti $\mathrm{C}_{3} \mathrm{H}$ and the White ddS. The ICF was a strain obtained by mating the $\mathrm{C}_{57} \mathrm{BL}$ with the black mouse of Chatterjee and then back crossing the $F_{1}$ with the Ind. Black as inbreeding of the black mouse sent by Chatterjee was not successful.

\section{INOCULATION METHOD AND MATERIALS}

Inoculum: The leproma of 3 untreated patients A, B, C was excised, stored under freezing for 1-3 months, finely ground in a mortar, emulsified in YLH ( tissue culture fluid), centrifuged to remove tissue debris, and a small quantity of india ink added to the supernatant. Each $0.1 \mathrm{ml}$ of the preparation contained about 2,000,000 bacilli.

Animal: Two-7 days old mice were used. The back was disinfected with alcohol and $0.1 \mathrm{ml}$ of the inoculum injected subcutaneously. The inoculated animals were left with the mother for 4 weeks and then placed separately in cages according to sex.

Conditions for Breeding: As the animal must be reared for 1-2 years, the environmental conditions must be maintained at an optimum. In our laboratory, experiments are being conducted with the murine leprosy bacillus so measures to prevent cross infection had to be taken. A separate animal room was built, the animal caretaker was made separate and the cages desinfected by autoclaving and bedding with pyrethrum powder.

Method of Examination: The animals were dissected and examined 10-24 months after inoculation. When a lesion was present in the skin, it was carefully examined and in cases where no lesion could be observed macroscopically, the spread preparation from tissue surrounding the site of inoculation, marked by the india ink, was examined. Smear specimens of lymphnodes and the organs were also prepared.

\section{RESULTS}

Lesions and bacterial proliferation were found macroscopically or microscopically in 14 of 711 animals (ca $2 \%) ; 8$ of $362(2.2 \%$ ) with inoculum material A, 5 of $204(2.5 \%)$ with B and 1 of $145(0.7 \%)$ with C.

Bacterial proliferation according to mouse strain was found in 5 of $257(1.9 \%)$ in the case of the ICF, 3 of $223(1.3 \%)$ in the $\mathrm{BK}, 5$ of $114(4.4 \%)$ in the $\mathrm{C}_{57} \mathrm{BL}$ and 1 of $45(2.2 \%)$ in the ddS, while no growth was observed in BTK or $\mathrm{C}_{3} \mathrm{H}$. Killed bacteria was inoculated in the control and no proliferation was found in any of the 111 animals. Of the 14 animals in which bacterial proliferation was 
Table 1. Chief Manifestations in Animals Bacterial Showing Proliferation

\begin{tabular}{|c|c|c|c|c|c|c|c|c|c|c|}
\hline \multirow[b]{2}{*}{$\begin{array}{l}\text { Exp. } \\
\text { No. }\end{array}$} & \multirow[b]{2}{*}{ 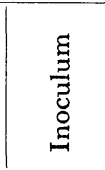 } & \multirow[b]{2}{*}{ 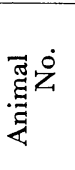 } & \multirow[b]{2}{*}{ Strain } & \multirow[b]{2}{*}{$\begin{array}{c}\text { Months After } \\
\text { Inoculation }\end{array}$} & \multirow[b]{2}{*}{$\begin{array}{l}\text { Macroscopic } \\
\text { Findings }\end{array}$} & \multicolumn{5}{|c|}{ Distribution of Bacillus } \\
\hline & & & & & & 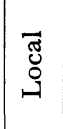 & 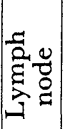 & 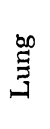 &. & 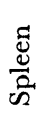 \\
\hline \multirow{5}{*}{ I } & \multirow{8}{*}{$\begin{array}{c}\text { A } \\
\%(362)\end{array}$} & $10-1$ & ICF & 10 & $\begin{array}{l}\text { Small nodule in back, } \\
\text { central necrosis }\end{array}$ & $\infty$ & H & - & + & - \\
\hline & & $10-3$ & ICF & 14 & $\begin{array}{l}\text { Medium sized } \\
\text { indurated node in back }\end{array}$ & + & - & - & - & - \\
\hline & & $11-1$ & $\mathrm{BK}$ & 13 & $\begin{array}{l}\text { Granulation and } \\
\text { infiltration } 3 \times 3 \mathrm{~mm} \\
\text { in size in back }\end{array}$ & $\infty$ & + & - & - & - \\
\hline & & $12-2$ & $\mathrm{BK}$ & 14 & $\begin{array}{l}\text { Granulation and } \\
\text { infiltration } 5 \times 6 \mathrm{~mm} \\
\text { in size in back }\end{array}$ & $\infty$ & + & - & - & - \\
\hline & & $16-1$ & BK & 10 & $\begin{array}{l}\text { Granulation and } \\
\text { infiltration } 3 \times 3 \mathrm{~mm} \\
\text { in size in back }\end{array}$ & $\infty$ & + & - & + & + \\
\hline \multirow{3}{*}{ II } & & $27-2$ & $\mathrm{ICF}$ & 19 & $\begin{array}{l}\text { Medium sized node } \\
\text { in back }\end{array}$ & $\infty$ & H & H & H & H \\
\hline & & $32-3$ & ICF & 19 & $\begin{array}{l}\text { Medium sized node } \\
\text { in back }\end{array}$ & $\infty$ & H & $H$ & H & $H$ \\
\hline & & $39-4$ & ddS & 19 & $\begin{array}{l}\text { Necrotic nest } 2 \times 6 \mathrm{~mm} \\
\text { in rump }\end{array}$ & $\infty$ & + & - & - & - \\
\hline \multirow{5}{*}{ IV } & \multirow{5}{*}{$\begin{array}{c}\text { B } \\
\%(204)\end{array}$} & $21-5$ & $\mathrm{C}_{57} \mathrm{BL}$ & 21 & $\begin{array}{l}\text { Small nodules in } \\
\text { lungs }\end{array}$ & $\perp$ & + & $H$ & - & - \\
\hline & & $21-8$ & $\mathrm{C}_{57} \mathrm{BL}$ & 21 & $\begin{array}{l}\text { Infiltration and } \\
\text { nodules in chest } \\
\text { wall and lungs }\end{array}$ & + & H & HH & H & H \\
\hline & & $22-2$ & $\mathrm{C}_{57} \mathrm{BL}$ & 21 & $\begin{array}{l}\text { Numerous nodules } \\
\text { in lungs }\end{array}$ & $\perp$ & $H$ & $\infty$ & + & H \\
\hline & & $22-3$ & $\mathrm{C}_{57} \mathrm{BL}$ & 21 & $\begin{array}{l}\text { Caseous change in } \\
\text { right lung }\end{array}$ & $\perp$ & H & $\infty$ & H & H \\
\hline & & $22-9$ & $\mathrm{C}_{57} \mathrm{BL}$ & 21 & $\begin{array}{l}\text { Infiltration of } \\
\text { entire subcutaneous } \\
\text { tissue of back }\end{array}$ & $\infty$ & H & $H$ & H & HH \\
\hline V & $\underset{\mathrm{C}}{\mathrm{C}}$ & $19-5$ & ICF & 19 & $\begin{array}{l}\text { No macroscopic } \\
\text { changes }\end{array}$ & H & + & - & - & - \\
\hline
\end{tabular}

found, 7 (2, 2 and 3$)$ of 3 groups were of the same litter and raised in the same cage. The 14 cases are presented in the Table 1 .

\section{IDENTIFICATION OF THE ORGANISM}

In order to ascertain whether the acid-fast organism growing in the lesion in the mouse was identical with that isolated from the leprosy patient, the followirg experiments were carried out. Control experiments with the murine leprosy bacillus were also conducted.

1) The isolated bacillus is somewhat smaller in form compared to the leprosy bacillus, and the globi are not as round and compact. The form is closer to that of the murine leprosy bacillus. 
2) The organism disappeared in 2-3 months following inoculation in the guinea pig. A granulomous lesion was formed by proliferation of the bacillus after 3-5 months in the rat.

3) There was no growth for 2 months on Löwenstein, Petragnani or Ogawa medium on incubation at $33^{\circ} \mathrm{C}$ or $37^{\circ} \mathrm{C}$.

4) Density of the bacillus in the lesion is greater compared to that in leprosy though there is invasion of the periferal nerves by the bacillus, there is no hypertrophy of the neural parenchyma or change in the neurofibrils. The hypertrophy of the vascular wall observed in the lesion in leprosy is not found. There is no marked invasion by the leprous foamy cells and the central part of the lesion shows a pronounced trend for necrosis.

5) The precipitation reaction using agar-diffusion by Ouchterlony with the rabbit immune serum failed to show a specific reaction with the leprosy bacillus antigen.

6) The complement fixation reaction using leprosy patient's serum absorbed with isolated bacillus showed no significant difference in value to leprosy bacillus antigen compared with the non-absorbed control.

7) The Lepromin reaction was tested in the leprosy patients. The antigen was prepared with leproma produced after serial passage in the mouse by the Mitsuda and the Dharmendra methods. The standard Lepromin was obtained from the National Institute for Leprosy Research.

The patients were selected from 5 leprosaria (Oshima Seishoen, Nagashima Aiseien, Oku Komyoen, Hoshizuka Keiaien and Suruga Leprosarium) and included 78 cases of the $\mathrm{L}$ type and 27 cases of the $\mathrm{T}$ type. The same method was used in all the cases. There was no significant difference compared to the standard Lepromin in the $\mathrm{T}$ type patients but in the $\mathrm{L}$ type, a difference was found as shown in the Fig. 1.

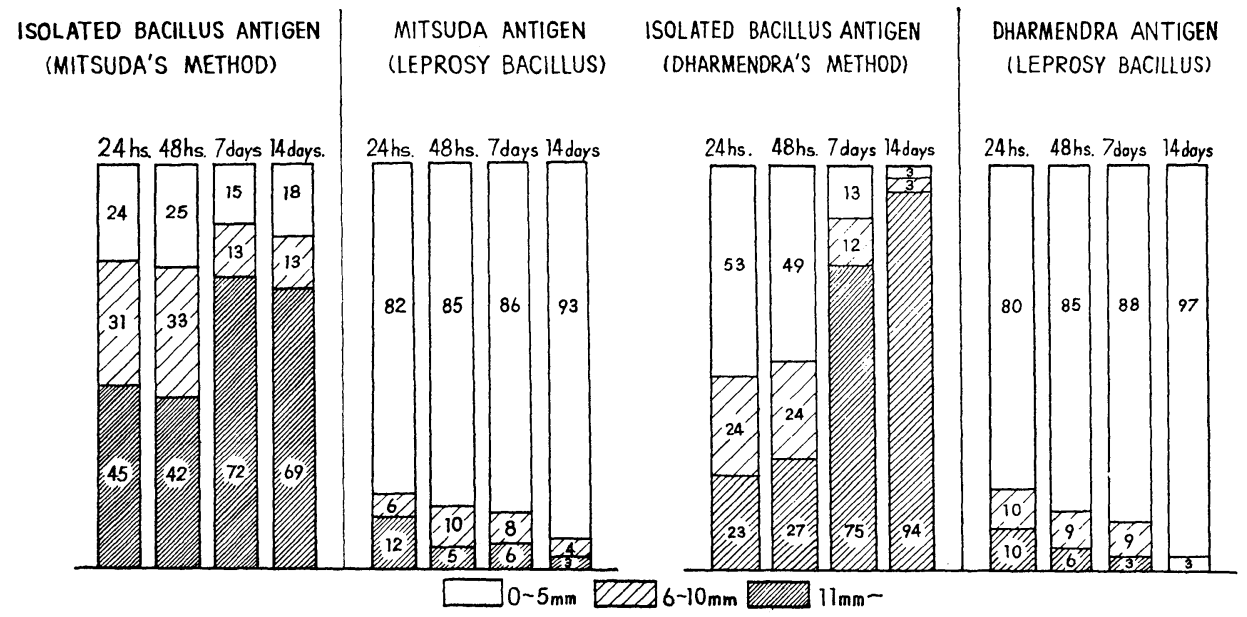

Fig. 1 Lepromin Reaction in L-type Patients (78 Cases)

The Lepromin reaction was examined in the $\mathrm{L}$ type cases with 11 strains besides the No. 10-1 strain used in the above experiment but there was no case coinciding with the standard. 
8) The attempt was made to clarify the biological specificity of the bacillus by amidase activity. More than 10 kinds of substrates were used but only representative samples are presented here. The amidase activity of the leprosy bacillus was investigated repeatedly but no constant result was obtained so will not be described here.\%

As can be seen in Table 2, a similar pattern was shown by 10 strains. The activity of 7 strains of murine leprosy bacilli maintained in the laboratory was compared. The Hawaiian and Kumamoto strains differed in that there was asparaginase activity but the Douglas, Pasteur, Kurume, Fukuoka and Keishicho strains showed the similar activity.

Table 2. Amidase Activity of the Proliferating Bacillus

\begin{tabular}{l|c|c|c|c}
\hline \hline Substrates & $\begin{array}{c}\text { Human Leprosy } \\
\text { Bacillus\% }\end{array}$ & $\begin{array}{c}\text { Isolated } \\
\text { Bacillus } \\
(10 \text { strains })\end{array}$ & \multicolumn{2}{|c}{ Murine Leprosy Bacillus } \\
\cline { 3 - 5 } & & - & - & 2 strains \\
\hline Formamide & & + & + & - \\
Caprylamide & & - & - & + \\
Urea & & - & + & + \\
Asparagine & & + & + & + \\
Nicotinamide & & - & - & + \\
Pyrazinamide & & - & + \\
Guanosine & & & & + \\
\hline
\end{tabular}

9) The sensitivity to chemotherapeutic agents was examined using DDS and INH. Bacterial emulsion was inoculated subcutaneously in groups of 20 mice each. DDS was given orally in a dose of $2 \mathrm{mg}$ daily for 6 days a week in 1 group and $0.2 \mathrm{mg}$ of INH was given orally in another group. The group was left untreated as the control. The animals were observed for a period of 26 weeks. As shown in Fig. 2 the leproma was markedly suppressed by INH while there was little difference between the DDS group and the control. The number of bacilli in the lymphnodes and organs was proportional to this and there were fewer in the INH group.

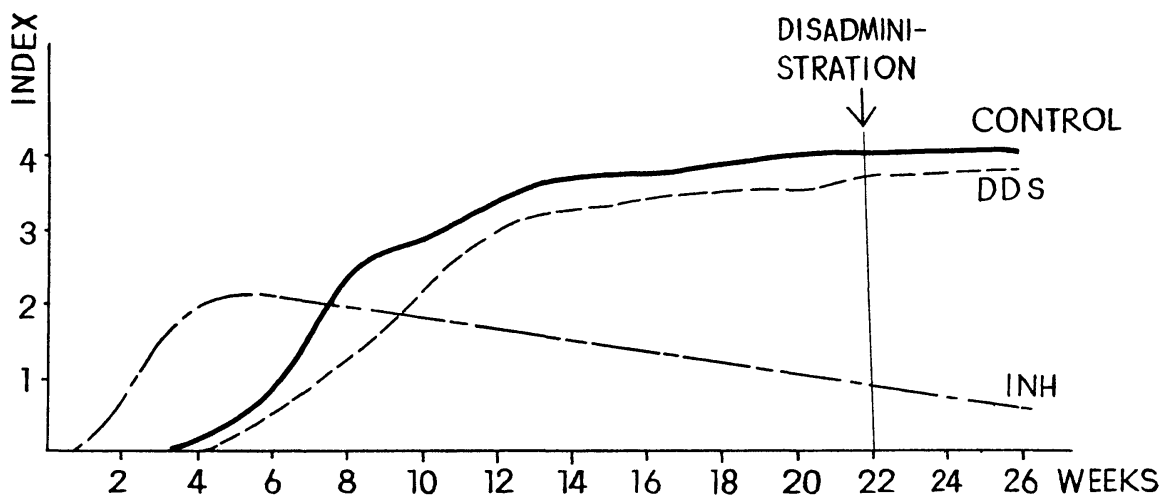

Fig. 2 Sensitivity of Isolated Bacillus (No. 10-1) to DDS and INH

From these results $(1-9)$, it is believed that the 14 strains of acid-fast bacilli 
differ from the leprosy bacillus isolated from the patient and are closer to the murine leprosy bacillus. It can also be reperceived that in the $\mathrm{L}$ type patients the Lepromin test with the isolated bacteria is the most simple and clear method for clarifying specificity of the leprosy bacillus.

\section{ORIGIN OF THIS ACID-FAST BACILLUS}

The finding that the proliferating bacillus was similar to the murine leprosy bacillus despite the careful measures taken in preventing contamination came as a shock. Two hypotheses were made as to the origin of this acid-fast bacillus.

One hypothesis is that a small part of the inoculated leprosy bacilli underwent a change, became adapted to the mouse cell and proliferated in $2 \%$ of the 711 animals. The other hypothesis is that an inapparent infection by murine leprosylike organism was already present in the apparently healthy animal and this was the source of contamination.

It is difficult to verify the first hypothesis of mutation experimentally at the present time. The second hypothesis may be more acceptable since acid-fast bacilli have been found in smears of skin tissue emulsions of healthy mice bred in the laboratory. The following 2 experiments were conducted in an attempt to clarify the origin of the organism. Quartz sand was injected subcutaneously in healthy mice to see whether a lesion by acid-fast bacillus could be induced. A total of 66 animals was tested but bacterial proliferation was not found after 7 months. But in only 1 case acid-fast bacterial clumps were observed microscopically at the inoculation site. The second expermiment was to carefully examine a large number of healthy mice for acid-fast bacillus. Connective tissue specimens from several sites in the skin and smears of the lymphnodes and organs were examined under the microscope.

As can be seen in Table 3, actual contamination was found to be more frequent than what we assumed before. Of a total of 396 animals acid-fast bacillus was found in 2\% of 97 animals reared for $1.5-6$ months, in $8 \%$ of 109 animals reared for $8-12$ months in our laboratory, in $13 \%$ of 40 animals reared for

Table 3. Isolation of Acid-fast Bacillus from Healthy Non-inoculated Mice

\begin{tabular}{|c|c|c|c|c|c|c|c|}
\hline Origin & $\begin{array}{c}\text { Place } \\
\text { of } \\
\text { Rearing }\end{array}$ & $\begin{array}{c}\text { Months } \\
\text { of } \\
\text { Rearing }\end{array}$ & $\begin{array}{l}\text { No. } \\
\text { Examined }\end{array}$ & 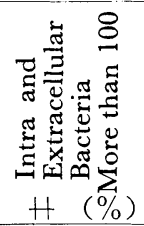 & $\begin{array}{l}\text { Solitary } \\
\text { Organisms } \\
20-30 \\
+\quad(\%)\end{array}$ & $\begin{array}{c}\text { Solitary } \\
\text { Organisms } \\
\text { Several } \\
+\quad(\%)\end{array}$ & Total \\
\hline & & $1.5-6$ & 97 & 0 & $1 \quad(1)$ & $1 \quad(1)$ & $2(2)$ \\
\hline Own Breed & $\begin{array}{l}\text { Leprosy } \\
\text { Laboratory } \\
\text { Animal Room }\end{array}$ & $8-12$ & 109 & $1 \quad(1)$ & $3 \quad(3)$ & $4 \quad(4)$ & $8(8)$ \\
\hline T Lab. & $\begin{array}{l}\text { Tuberculosis } \\
\text { Laboratory } \\
\text { Animal Room }\end{array}$ & $4-12$ & 40 & (5) & 0 & $3 \quad(8)$ & $5 \quad(13)$ \\
\hline N District & Animal Farm & 12 & 77 & $(8)$ & $6 \quad(8)$ & $6 \quad(8)$ & $18 \quad(24)$ \\
\hline G District & Animal Farm & 12 & 73 & (7) & $7 \quad(10)$ & $10 \quad(14)$ & $22 \quad(31)$ \\
\hline
\end{tabular}


4-12 months in T laboratory, in 24\% of 77 animals reared for 12 months at the $\mathrm{N}$ animal farm and in $31 \%$ of 73 animals reared for more than 12 months in the $\mathrm{G}$ district. Only several solitary acid-fast bacilli were found in some specimens but in others, there were groups of bacilli both inside and outside of the cells.

The attempt is being made to cultivate these organisms in cultures and to serially pass them in mice. The details will be published later. At the present stage, 2 cases have been successfully passed in mice and found to be similar to the murine leprosy bacillus. From this, it may be said that inapparent infection with murine leprosy bacillus could be present among mice contaminated with acid-fast bacillus.

\section{SUMMARY}

1) The human leprosy bacillus was inoculated subcutaneously in 711 animals of 4 strains of black mouse (ICF, BK, $\mathrm{C}_{57} \mathrm{BL}, \mathrm{BTK}$ ), $\mathrm{C}_{3} \mathrm{H}$ and ddS, but proliferation of leprosy bacilli was not found.

2) Identification tests were carried out on 14 acid-fast bacilli which proliferated and these were found to be similar to the murine leprosy bacillus.

3) The Lepromin reaction was found to be the most simple and accurate for identification of the leprosy bacillus.

4) Contamination by acid-fast bacillus was investigated in 396 healthy, noninoculated mice and a high percentage, not only animals bred in the laboratory but obtained elsewhere, was found to be contaminated with the organism.

5) Inapparent infection by murine leprosy bacillus was found among the healthy mice. In other words, murine leprosy bacillus of mouse origin was discovered.

6) The acid-fast bacilli isolated in the present study are believed to originate from animals with inapparent murine leprosy infection.

7) Measures must be taken to prevent contamination by organisms such as these in conducting investigations in animals and the initial step following isolation of an organism should be to examine the Lepromin reaction.

(This study was partially indebted by a grant from WHO)

\section{REFERENGES}

1) Tanimura, T. and S. Nishimura: A Review of Recent Animal Inoculation Studies with Human and Murine Leprosy Bacilli. Internat. J. Leprosy 21, 335-346 (1953)

2) Tanimura, T., S. Nishimura and K. Ogita: On the Sensitivity of Hamster to the Human and Murine Leprosy Bacillus. La Lepro 21, 181-186 (1952)

3) Nishimura, S., M. Nakao and K. Kosaka; On the Strain of Mice for the Experimental Murine Leprysy. Bull. Exp. Animals 4, 27-29 (1955)

4) Nishimura, S.: Susceptibility of Wild Rodents to the Murine Leprosy Bacillus. Internat. J. Leprosy 28, 428-440 (1960).

5) Chatterjee, K. R.: Experimental Transmission of Human Leprosy Infection to a Selected Laboratory-bred Hybrid Black Mouse. Internat. J. Leprosy 26, 195-204 (1958) 


\section{EXPLANATION OF PLATE I}

Fig. 1 Exp. I, No. 10-1 : Subcutaneous lesion, 10 months after inoculation

Fig. 2 ditto : Acid-fast bacilli in stamp smear (Z.N)

Fig. 3 ditto : Subcutaneous lesion in rat, 3 months after secondary inoculation (Z.H) Numerous bacilli are seen.

Fig. 4 Exp. I, No. 10-3 : Lesion of medium size node, 14 months

Fig. 5 ditto : Acid-fast bacilli in stamp smear (Z.N) Several bacilli are seen.

Fig. 6 ditto : Proliferation of bacilli in nerve of subcutaneous lesion of secondary inoculated mouse $(\mathrm{Z} . \mathrm{H})$ 
PLATE I

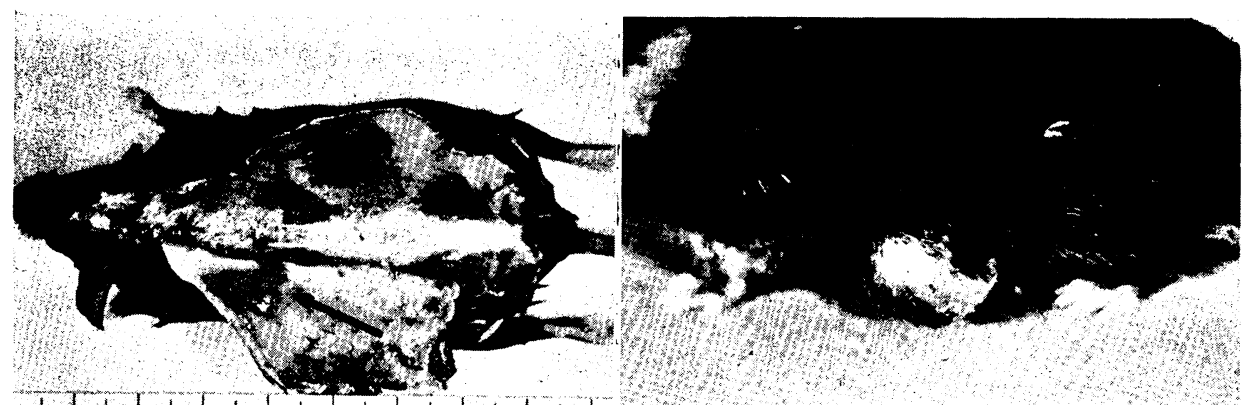

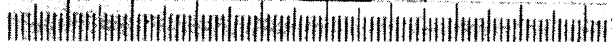

Fig. 1

Fig. 4

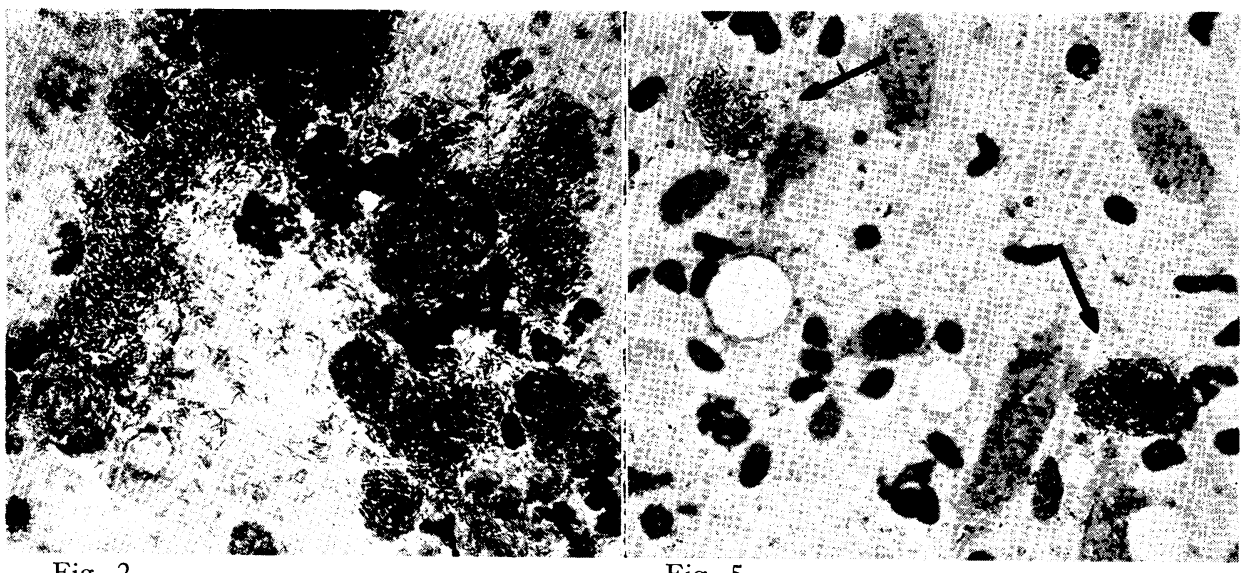

Fig. 2

Fig. 5

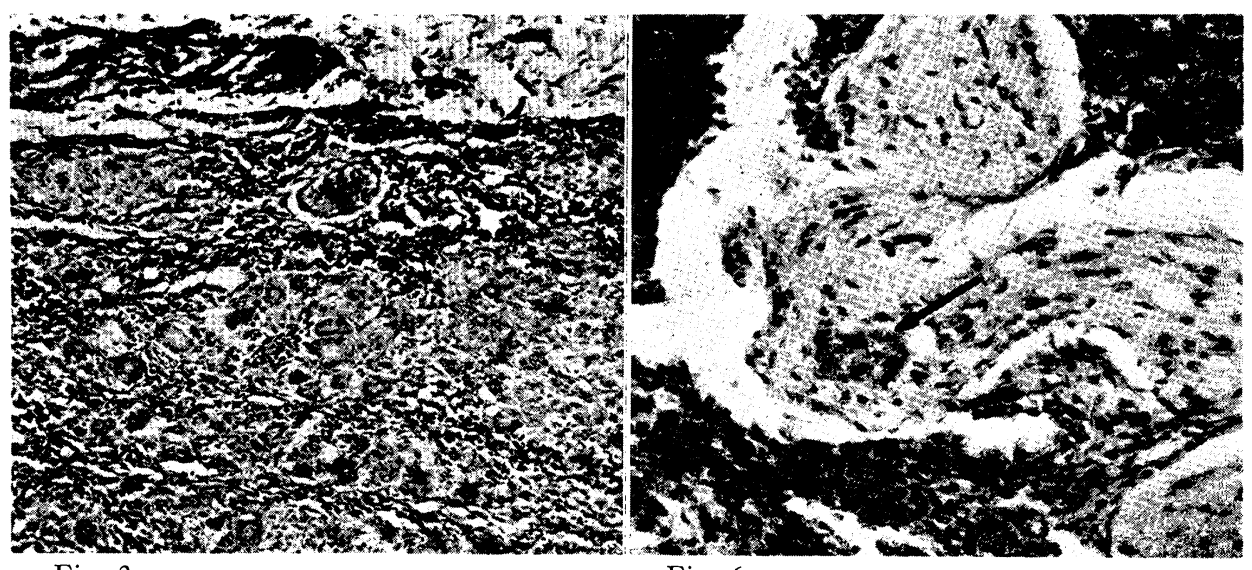

Fig. 3

Fig. 6 


\section{EXPLANATION OF PLATE II}

Fig. 7 Exp. I, No. 10-3 : Nerve in lesion of primary infected mouse (Suzuki) There is significant hypertrophy of Henle's sheath but no change of nerve cells.

Fig. 8 ditto : Fibroma like lesion (H.E) Some giant cells are seen.

Fig. 9 Exp. II, No. 32-3: Subcutaneous lesion of primary infected mouse (H.E)

Lesion shows necrosis and there is no vacuole in lepra cells.

Fig. 10 ditto : Leproma in liver (H.E)

Fig. 11 ditto : Leproma in pleura (H.E)

Central part of leproma shows a trend for necrosis. 
PLATE II
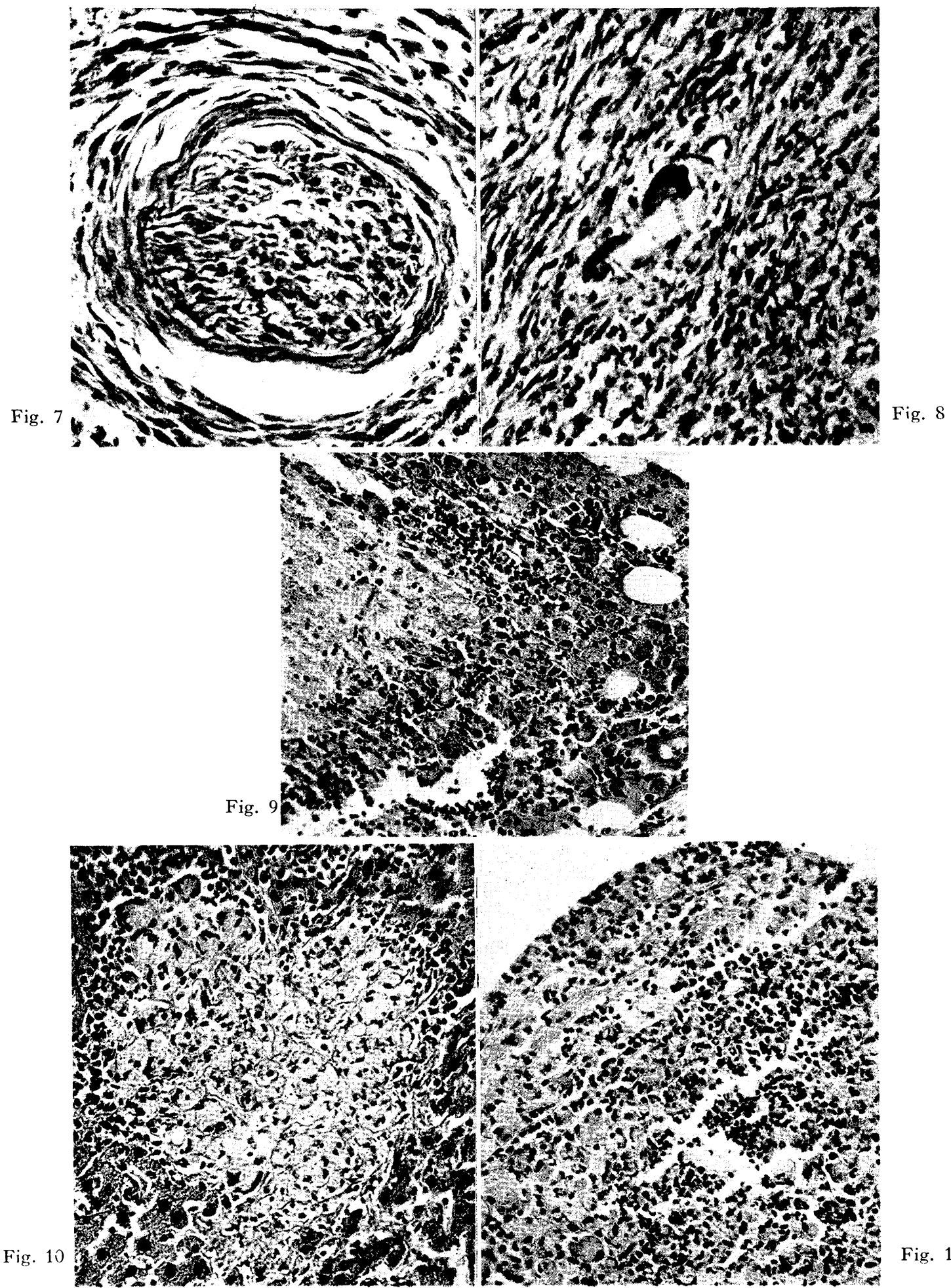


\section{EXPLANATION OF PLATE III}

Fig. 12 Exp. I, No. 23-1 : Control inoculated with heat killed bacilli, 10 months (Spread smear, Z.N)

It shows globi in cells ingested india ink.

Fig. 13 Healthy mouse No. 1: Bacillary clumps in spread smear of subcutaneous connective tissue (Z.N)

Fig. 14 ditto : Secondary passage mouse, 12 months, Proliferation of bacilli in stamp smear of lungs (Z.N)

Fig. 15 Healty mouse No. 394: Bacillary clumps in spread smear of subcutaneous connective tissue (Z.N)

Fig. 16 Healty mouse No. 391: Several bacilli in stamp smear of inguinal lymphnode $(\mathrm{Z} . \mathrm{N})$ 
PLATE III

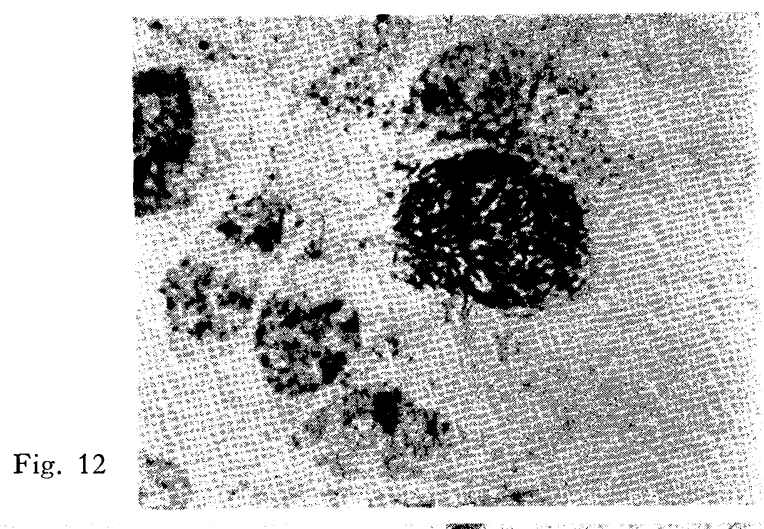

Fig. 13

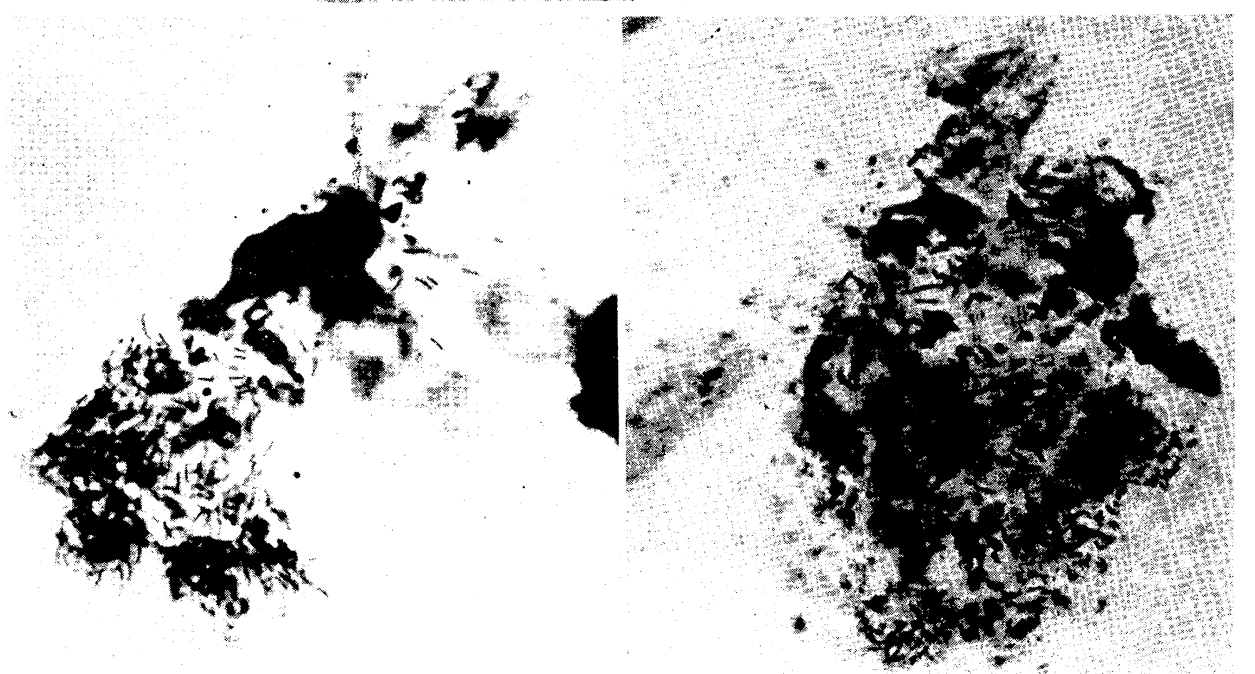

Fig. 1!

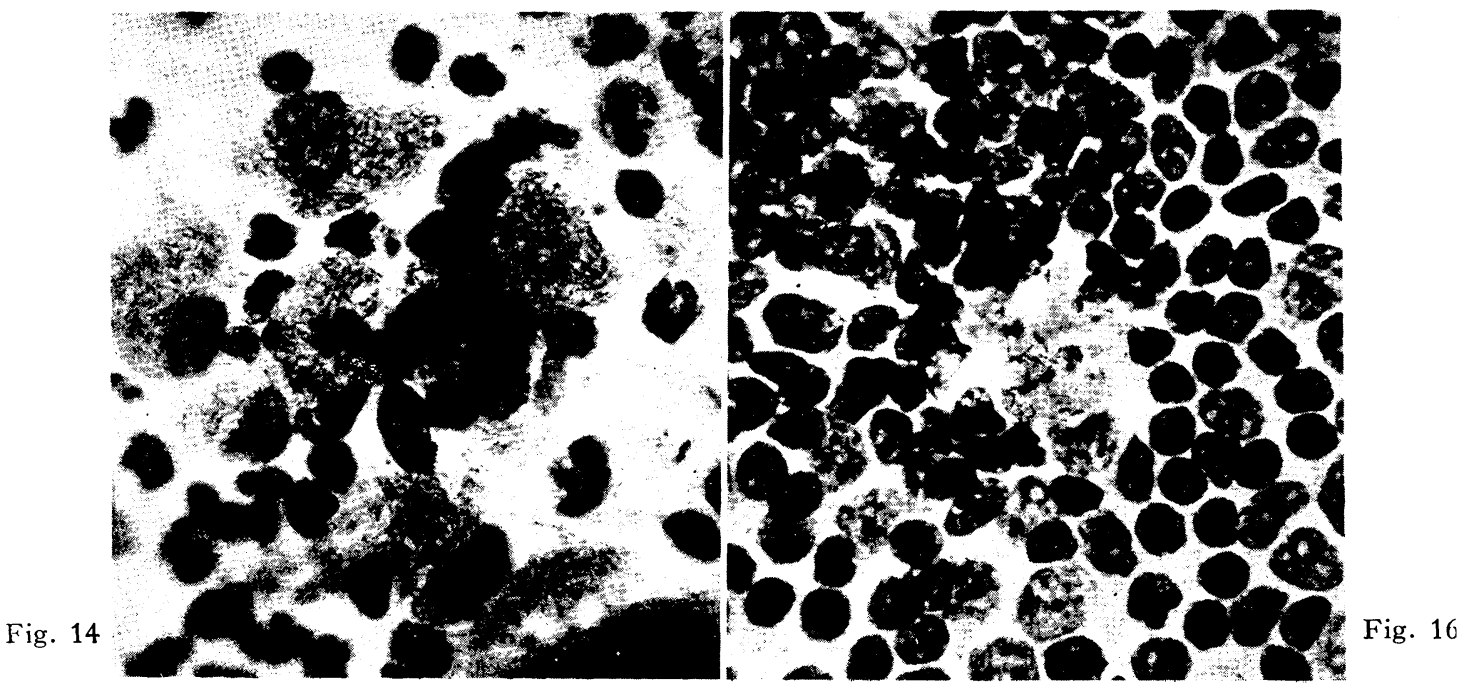

